\title{
PHARMACOECONOMIC ASPECTS OF HELMINTHIASIS TREATMENT IN PEDIATRICS
}

\author{
M.A. Ezhned, O.I. Zakharchuk, O.M. Horoshko, M.R. Matushchak, L.V. Kostyshyn, \\ I.M. Sakhatska, N.A. Fediuk, N.V. Mykhailiuk, V. L. Voloshyn
}

HSEE of Ukraine «Bukovinian State Medical University», Chernivtsi

The problem of parasitosis is quite pressing today, as the morbidity remains one of the most common in the world. According to the statistics, every third inhabitant of the planet is infected with one or another helminth, often 2-3 or even more of their species. In Ukraine 400-600 thousand patients with helminthiasis are registered each year, which is $53 \%$ of all infectious diseases, $80 \%$ of the identified patients are children. However, based on sales of anthelmintic drugs, the number of infected parasites can be several times higher.

Objective - to optimize the reduction of helminthiasis treatment cost by conducting a pharmacoeconomic analysis of the anthelmintic drugs use.

Material and methods. In order to monitor the state of the pharmaceutical market of antiparasitic drugs, we analyzed 83 medical records of inpatients (children aged 1 to 14 years) for worm infestations and medical records of medical institutions in Chernivtsi.

Results. According to the results of pharmacoeconomic analysis "cost minimization", it was found that in the age category of 1-2 years while using a suspension of "Vormil»" and "Zentel», there was no significant difference in the price of drugs for the treatment course. "Angelmex» (45\%), "Vormil» (35\%) and "Zentel» (15\%) are used in the age group of 2-6 years. In the age group of 6-12 years, the choice of drug depends mostly on the dosage form, in $20 \%$ of cases more often they choose chewable tablets, due to the more comfortable way of use, regardless of the drug's price.

In the second stage of the research, a pharmacoeconomic analysis of the dietary supplements use for the helminthiasis prevention was performed. The cheapest for the treatment course was "Phytoglistocide» in the form of capsules (126,83 UAH) and syrup $(275,88 \mathrm{UAH})$, and the most expensive - "Vormil Phyto» in the form of syrup (444,6 UAH).

Conclusions. According to the results of the conducted researches it has been established that enterobiasis remains the most widespread in the Chernivtsi region area. Albendazole group agents in the form of tablets and suspensions are most commonly used in these helminthiasis treatment. The drugs of choice are "Algelmex», "Vormil», "Zentel», the choice of which depends on the age category.

\section{ФАРМАКОЕКОНОМІЧНІ АСПЕКТИ ЛІКУВАННЯ ГЕЛЬМІНТОЗІВ У ПЕДІАТРІї}

М.А. Еэнед, О.І. Захарчук, О.М. Горошко, М.Р. Матущак, Л.В. Костишин, І.М. Сахацька, Н.А. Федюк, Н.В. Михайлюк, В.Л. Волошин

Проблема паразитозів є досить актуальною на сьогоднішній день, оскільки залишається однією із найбільш потирених у світі. Згідно з даними статистики, кожен третій житель планети заражений тим чи іншим гельмінтом, нерідко одночасно двома-трьома або навіть більшою кількістю їх видів. Щороку в Украйні реєструються 400-600 тисяч хворих на гельмінтози, щз становить 53\% всієі інфекиійної захворюваності, 80\% від числа виявлених хворих сстановлять діти. Проте виходячи з обсягів продажу антигельмінтних препаратів, кількість заражених паразитами може бути в декілька разів більиа.

Мета роботи - оптимізація зменшення вартості лікування гельмінтозів иляхом проведення фармакоекономічного аналізу застосування антигельмінтних npenapamis.

Матеріал і методи. 3 метою здійснення моніторингу стану фармацевтичного ринку протипаразитарних засобів нами проведено аналіз 83 медичних карт стаціонарних хворих (діти віком від 1 до 14 років) на глистяні інвазії та листків лікарських призначень лікувальних установ м. Чернівці.

Результати. 3 а результатами фармакоекономічного аналізу «мінімізація витрат» встановлено, щзо у віковій категорії 1-2 роки при використанні суспензї «Ворміл» та «Зентел» суттєвої різниці у ичіні препаратів на курс лікування немає. У віковій категорії 2-6 років використовуються препарати «Ангельмекс» (45\%), Клінічна та експериментальна патологія. 2020. Т.19, № 3 (73)
Key words:

helminthiasis,

pharmacoeconomic

analysis, pediatrics,

anthelmintic drugs.

Clinical and experimental pathology. Vol.19, №3

(73). P.17-24.

DOI:10.24061/1727-4338. XIX.3.73.2020.3

E-mail: mariaezhned@bsmu.edu. ua

\section{Ключові слова:}

гельмінтози, фармакоекономічний аналіз, педіатрія, антигельмінтні препарати.

Клінічна та експериментальна патологія 2020. T.19, №3(73). C.17-24. 
«Ворміл» (35\%) та «Зентел» (15\%). У віковій категорії 6-12 років вибір препарату залежить здебільшого від лікарської форми, у 20\% випадків частіше вибирають жувальні таблетки, що пояснюється більи комфортним способом вживання, не зважаючи на ціну препарату.

На другому етапі досліджень проведено фармакоекономічний аналіз застосування дієтичних добавок для профілактики гельмінтозів. Найдешевшим на курс лікування був «Фітоглистоичд» як у формі капсул (126,83 грн), так $і$ сиропу (275,88 грн.), а найдорожчим - «Ворміл Фіто» у формі сиропу (444,6 грн.)

Висновки. За результатами проведених досліджень встановлено, щзо найбільш розповсюдженим на території області залишається ентеробіоз. Найбільше використовуються при даних гельмінтозах засоби групи альбендазолу у формі таблеток та суспензії. Препаратами вибору є «Ангельмекс», «Ворміл», «Зентел», вибір яких залежить від вікової категорії.

\section{Ключевые слова:} гельминтозы, фармакоэкономический анализ, педиатрия, антигельминтные преnapambl.

Клиническая и экспериментальная патология T.19, №3 (73). C.17-24.

\section{ФАРМАКОЭКОНОМИЧЕСКИЕ АСПЕКТЫ ЛЕЧЕНИЯ ГЕЛЬМИНТОЗОВ В ПЕДИАТРИИ}

\section{М.А. Эжсне, А.И. Захарчук, А.М. Горошко, М.Р. Матущак, Л.В. Костишин, И.М. Сахацкая, Н.А. Федюк, Н.В. Михайлюк, В.Л. Волошин}

Проблема паразитозов является весьма актуальной на сегодняшний день, посколько остается одной из самых распространенных в мире. Согласно данным статистики, каждый третий житель планеты заражен тем или иным гельминтом, нередко одновременно двумя-тремя или даже большим количеством их видов. Ежегодно в Украине регистрируются 400-600 тысяч больных гельминтозами, что составляет 53\% всей инфекциионной заболеваемости, 80 \% от числа выявленных больных составляют дети. Однако, исходя из объемов продаж антигельминтных препаратов, количество зараженных паразитами может быть в несколько раз больше.

Цель работы - оптимизация уменьшения стоимости лечения гельминтозов путем проведения фармакоэкономического анализа применения антигельминтных nрепаратов.

Материал и методы. С иелью осущчествления мониторинга состояния фармацевтического рынка противопаразитарных средств нами проведен анализ 83 медицинских карт стационарных больных (дети в возрасте от 1 года до 14 лет) на глистные инвазии и листов лекарственных назначений лечебных учреждений 2. Черновизы.

Результаты. По результатам фармакоэкономического анализа «минимизация затрат» установлено, что в возрастной категории 1-2 лет при использовании суспензии «Вормил» и «Зентела» существенной разнищы в ичене препаратов на курс лечения нет. В возрастной категории 2-6 лет используются препарать «Ангельмекс» (45\%), «Вормил» (35\%) и «Зентела» (15\%). В возрастной категории 6-12 лет выбор препарата зависит в основном от лекарственной формы, в 20\% случаев чащче выбирают жевательные таблетки, что объясняется более комфортным способом употребления, несмотря на цену препарата.

На втором этапе исследований проведено фармакоэкономический анализ применения диетических добавок для профилактики гельминтозов. Самым дешевым на курс лечения был «Фитоглистоцид»как в форме капсул (126,83 грн), так и в форме сиропа (275,88 грн.), а самым дорогим - «Вормил Фито» в форме сиропа (444,6 грн.)

Выводы. По результатам проведенных исследований установлено, что наиболее распространенным на территории области остается энтеробиоз. Больше всего используются при данных гельминтозах средства группь альбендазола в форме таблеток и суспензии. Препаратами выбора являются "Ангельмекс», «Вормил», «Зентел», выбор которых зависит от возрастной категории.

\section{Introduction}

The problem of parasitosis is quite relevant today, as the morbidity remains one of the most common in the world. According to the statistics, every third inhabitant of the planet is infected with one or another helminth, often 2-3 or even more of their species. According to the
World Health Organization, the number of patients with helminthiasis in the world is about 1.5 billion people [13]. The number of parasites that have being studied is growing every year, so currently 350 species of helminths which can cause human diseases are known, 30 of which are common in Ukraine [4-5]. 
Among all parasitic diseases, about $90 \%$ are helminthiasis. Worm infestations (helminthiasis) are widespread mass parasitic diseases that cause helminths to enter the human or animal body, followed by the development of complex relationships between helminths and the host body.

In Ukraine 400-600 thousand patients with helminthiasis are registered each year, that constitutes $53 \%$ of all infectious diseases, $80 \%$ of the identified patients are children [1, 6-7]. However, based on sales of anthelmintic drugs, the number of infected parasites can be several times higher.

The urgency of the problem is primarily due to the high prevalence, adverse effects on the child's body, variety of clinical manifestations, which, in its turn, complicates the diagnosis of these diseases, lack of immunity and prevention methods [8].

\section{Objective}

Optimization of reducing the helminthiasis treatment cost by conducting pharmacoeconomic analysis of the anthelmintic drugs use.

\section{Material and methods}

In order to monitor the state of the pharmaceutical market of antiparasitic drugs, we conducted a marketing study and analysis of the market of trade names and dosage forms. 83 medical records of inpatients (children aged 1 to 14 years) for worm infestations and medical records of medical institutions in Chernivtsi were also analyzed. Pharmacoeconomic studies by using the method of "cost minimization" allowed to compare the cost (in monetary terms) performance indicators.

\section{Results and discussion}

Invasion occurs in several ways: with food, water (alimentary), with the saliva of the vector (transmissible) and active penetration through the body (percutaneous), which causes the parasite infestation in all organs and tissues of the "host" [8-9].

The course of the most helminthiasis is quite long and is characterized by the diverse clinical picture - from asymptomatic manifestations to severe forms. Some helminths, penetrated into the human body, in the process of development can delay the mental and physical development of the "host", cause allergies and suppress immunity. Manifestations of the helminthiasis, both general and specific, are expressed in fever, headache, swollen lymph nodes, which can be interpreted as a viral infection; skin rashes disguise as atopic dermatitis; feeling of discomfort in the abdomen, morning sickness, gnashing of teeth while sleeping and weight loss [9].

We analyzed the morbidity of helminthiasis in children of Chernivtsi region. According to the results of the statistical study, the children morbidity in rural areas is $30 \%$ higher than in cities, which can be explained by the higher degree of contamination with eggs of helminths in the environment.

By age category, children of the age 2-7 years are more likely to get sick due to repeated infections because of the lack of personal hygiene skills. In children under 6 years, the helminthiasis morbidity was the highest and constituted about $70 \%$, at the age of $6-10$ years $-18 \%$ and at the age of 10-14 years was slightly lower, about $12 \%$ (Fig. 1). At the same time, the morbidity by sex did not differ significantly and was $48.2 \%$ for boys and $51.8 \%$ for girls.

-1-6 years old $\square$ 6-10 years old $\square 10-14$ years old

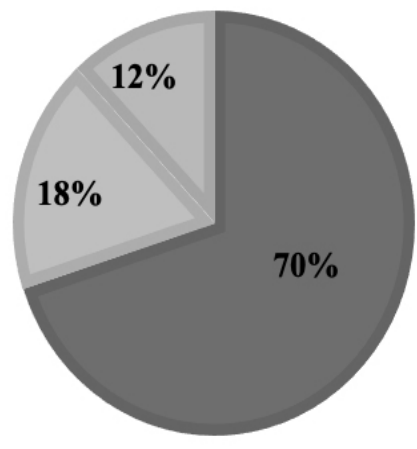

Figure 1. The helminthiasis morbidity in children depending on age

After retrospective analysis of medical records, it was found that the most common helminthiasis in children was diagnosed with enterobiasis (75\%), ascariasis (19\%), trichocephaly (4\%), the morbidity of other parasitic diseases was just $2 \%$. The main active substances of synthetic anthelmintic drugs, prescribed for these diseases treatment, are mebendazole, albenzazole, pyrantel pamoate, levamisole and piperazine adipate. Since enterobiosis remains the most common in the region, the pharmacoeconomic analysis took into account the drugs that were mainly used in these helminthiasis in different age groups. An important step is the choice of dosage form for different age categories, so the drugs of choice were drugs of the albendazole group in the form of tablets (Albela, Albendazole, Aldazole, Vormil, Zentel) and in suspension (Zentel and Vormil) (table 1).

Table 1

The dosage of drugs of the albendazole group in different groups

\begin{tabular}{|c|c|c|c|c|c|}
\hline Drugs & \multirow[b]{2}{*}{ Dosage form } & \multicolumn{4}{|c|}{ Age } \\
\hline Trade name & & 1-2 years old & $\begin{array}{l}2-3 \text { years } \\
\text { years old }\end{array}$ & $\begin{array}{l}\text { 3-6 years } \\
\text { years old }\end{array}$ & $\begin{array}{c}\text { 6-12 years years } \\
\text { old }\end{array}$ \\
\hline Vormil & & $5 \mathrm{ml}(200 \mathrm{mg}) 1$ & \multirow{2}{*}{\multicolumn{3}{|c|}{$10 \mathrm{ml}$ (400 mg) 1 time per day, once }} \\
\hline Zentel & suspension & time per day, once & & & \\
\hline
\end{tabular}


Continuation Table 1

\begin{tabular}{|c|c|c|c|c|}
\hline Albela & \multirow{3}{*}{ tablets } & - & - & \multirow{5}{*}{$\begin{array}{l}1 \text { tablet ( } 400 \\
\mathrm{mg} \text { ) once with } \\
\text { repeated use after } \\
3 \text { weeks }\end{array}$} \\
\hline Aldazole & & - & - & \\
\hline Zentel & & - & - & \\
\hline Angelmex & \multirow{3}{*}{$\begin{array}{l}\text { chewable } \\
\text { tablets }\end{array}$} & - & - & \\
\hline Albendazole & & - & - & \\
\hline Vormil & & - & \multicolumn{2}{|c|}{$\begin{array}{l}1 \text { tablet }(400 \mathrm{mg}) \text { once with repeated use after } \\
3 \text { weeks }\end{array}$} \\
\hline
\end{tabular}

In addition to synthetic anthelmintic drugs for the helminthiasis treatment, in order to prevent and mitigate the course of the disease herbal supplements in the form of capsules and syrups were also prescribed (Table 2).

The dosage of herbal dietary supplements in the most common helminthiasis

Table 2

\begin{tabular}{|c|c|c|c|c|}
\hline Drugs & \multirow{2}{*}{$\begin{array}{l}\text { Dosage } \\
\text { form }\end{array}$} & \multicolumn{3}{|c|}{ Age } \\
\hline Trade name & & 3-6 years old & 6-12 years old & $\begin{array}{l}\text { Adults and children } \\
\text { from } 12 \text { years old }\end{array}$ \\
\hline Vormil Phyto & \multirow{6}{*}{ syrup } & $\begin{array}{l}2,5-5 \mathrm{ml} 2 \text { times } \\
\text { per day, } 20 \text { days }\end{array}$ & $\begin{array}{c}\text { 5-10 ml } 2 \text { times per } \\
\text { day, } 20 \text { days }\end{array}$ & $\begin{array}{c}10 \mathrm{ml} 3 \text { times per day, } \\
20 \text { days }\end{array}$ \\
\hline Vormitel & & $\begin{array}{c}5 \mathrm{ml} 2 \text { times per } \\
\text { day, } 14 \text { days }\end{array}$ & $\begin{array}{c}5 \mathrm{ml} 3 \text { times per } \\
\text { day, } 14 \text { days }\end{array}$ & $\begin{array}{c}10 \mathrm{ml} 2 \text { times per day, } \\
14 \text { days }\end{array}$ \\
\hline Helmizin & & $\begin{array}{c}5 \mathrm{ml} 3 \text { times per } \\
\text { day, } 14 \text { days }\end{array}$ & $\begin{array}{l}10 \mathrm{ml} 2 \text { times per } \\
\text { day, } 14 \text { days }\end{array}$ & $\begin{array}{c}20 \mathrm{ml} 2 \text { times per day, } \\
14 \text { days }\end{array}$ \\
\hline Helmiplant & & $\begin{array}{c}5 \mathrm{ml} 2 \text { times per } \\
\text { day, } 7 \text { days }\end{array}$ & $\begin{array}{l}\text { 7,5 } \mathrm{ml} 2 \text { times per } \\
\text { day, } 7 \text { days }\end{array}$ & $\begin{array}{c}10 \mathrm{ml} 2 \text { times per day, } \\
7 \text { days }\end{array}$ \\
\hline $\begin{array}{l}\text { Kuchikoo from } \\
\text { helmints }\end{array}$ & & $\begin{array}{c}5 \mathrm{ml} 2 \text { times per } \\
\text { day, } 20 \text { days }\end{array}$ & $\begin{array}{l}5 \mathrm{ml} 3 \mathrm{p} \text { times per } \\
\text { day, } 20 \text { days }\end{array}$ & $\begin{array}{c}10 \mathrm{ml} 2 \text { times per day, } \\
20 \text { days }\end{array}$ \\
\hline Phytoglistocide & & - & $\begin{array}{c}5 \mathrm{ml} 2 \text { times per } \\
\text { day, } 18 \text { days }\end{array}$ & $\begin{array}{c}5 \mathrm{ml} 3 \text { times per day, } 19 \\
\text { days }\end{array}$ \\
\hline Vormil Phyto & \multirow{2}{*}{ capsules } & - & $\begin{array}{l}1 \text { caps. } 2 \text { imes per } \\
\text { day, } 20 \text { days }\end{array}$ & $\begin{array}{l}1 \text { caps. } 3 \text { times per day, } \\
20 \text { days }\end{array}$ \\
\hline Phytoglistocide & & - & $\begin{array}{l}1 \text { caps. } 2 \text { times per } \\
\text { day, } 18 \text { days }\end{array}$ & $\begin{array}{c}1 \text { caps. } 3 \text { times per day, } \\
19 \text { days }\end{array}$ \\
\hline
\end{tabular}

Pharmacoeconomic analysis by using the method of the "cost minimization" consisted in optimizing the reduction of the cost of drug therapy with anthelmintic drugs under conditions of equal clinical efficacy and included 2 stages.

At the first stage, the calculations of pharmacoeconomic indicators of treatment, using synthetic anthelmintic drugs, most often prescribed by a doctor, were performed. Data on the cost of these drugs were taken at the time of the study (August 2020) from 6 pharmacy networks in Chernivtsi. According to the results of pharmacoeconomic analysis "cost minimization", it was found that in the age category of 1-2 years old while using a suspension of «Vormil» and «Zentel», there was no significant difference in the price of drugs for the treatment course. Thus, conducting the statistical studies of retail chains on the sale of anthelmintic drugs in pharmacies in Chernivtsi, was found that the demand for «Vormil» is $10 \%$ higher than the suspension of «Zentel», which can be explained by a more well-known manufacturer. In the age group of 2-6 years, the most commonly used drugs are «Angelmex» (Agropharm LLC, Ukraine), «Vormil» (Mili Healthcare, Great Britain) and «Zentel» (GlaxoSmithKline, South Africa). The demand for these drugs was $45 \%, 35 \%$ and $15 \%$, respectively, which can be explained by the lowest price for the treatment course with «Angelmex», despite the fact that the price of one package is 1.45 higher than the price of «Vormil», and 1.23 times higher than «Zentel». However, for a full treatment course, considering the reappointment or treatment of all family members, «Angelmex» is cheaper than the appropriate study drugs. In the age group of 6-12 years, the demand for the studied drugs did not differ significantly, which can be explained by almost the same pricing policy of one package. The choice of drug depends mainly on the dosage form (in $20 \%$ of cases they mostly choose chewable tablets, due to the more comfortable way of use, regardless of the drug's price) (table 3). 
The calculation of costs for a course of treatment with anthelmintic drugs

Table 3

\begin{tabular}{|c|c|c|c|c|c|c|}
\hline № & Drugs & $\begin{array}{c}\text { The form of drug } \\
\text { release }\end{array}$ & $\begin{array}{l}\text { Manufacturer, } \\
\text { country }\end{array}$ & $\begin{array}{c}\text { The average } \\
\text { cost of } \\
\text { packaging, } \\
\text { UAH }\end{array}$ & $\begin{array}{c}\text { The cost } \\
\text { of the } \\
\text { daily dose, } \\
\text { UAH }\end{array}$ & $\begin{array}{c}\text { The cost of } \\
\text { treatment } \\
\text { course, } \\
\text { UAH }\end{array}$ \\
\hline 1. & Albela & $\begin{array}{c}\text { tablets } 400 \mathrm{mg} \text { blister, } \\
\text { № } 3\end{array}$ & $\begin{array}{l}\text { Kusum pharm } \\
\text { LLC, Ukraine }\end{array}$ & 69,30 & 23,10 & 46,20 \\
\hline 2. & Albendazole & $\begin{array}{c}\text { chewable tablets } 400 \mathrm{mg} \\
\text { blister, № } 3\end{array}$ & $\begin{array}{l}\text { Ternopharm LLC, } \\
\text { Ukraine }\end{array}$ & 60,20 & 20,10 & 40,20 \\
\hline 3. & Aldazole & $\begin{array}{c}\text { pellicle coated tablets } 400 \\
\text { mg blister, № } 3\end{array}$ & $\begin{array}{c}\text { JSC "Kyiv } \\
\text { Vitamin Plant", } \\
\text { Ukraine }\end{array}$ & 76,25 & 25,4 & 50,80 \\
\hline 4. & Angelmex & $\begin{array}{c}\text { chewable tablets } 400 \mathrm{mg} \\
\text { blister, № } 3\end{array}$ & $\begin{array}{c}\text { Agropharm LLC, } \\
\text { Ukraine }\end{array}$ & 53,65 & 17,90 & 35,80 \\
\hline 5. & \multirow{3}{*}{ Vormil } & $\begin{array}{c}\text { chewable tablets } 400 \mathrm{mg} \\
\text { blister, № } 1\end{array}$ & \multirow{3}{*}{$\begin{array}{l}\text { Mili Healthcare, } \\
\text { United Kingdom }\end{array}$} & 37,00 & 37,00 & 74,00 \\
\hline 6. & & $\begin{array}{c}\text { chewable tablets } 400 \mathrm{mg} \\
\text { blister, № } 3\end{array}$ & & 100,20 & 33,40 & 66,80 \\
\hline 7. & & $\begin{array}{c}\text { oral suspension (200 mg / } \\
5 \mathrm{ml}) \text {, vial } 10 \mathrm{ml} \text {, № } 1 \\
\end{array}$ & & 67,30 & 67,30 & 67,30 \\
\hline 8. & \multirow{2}{*}{ Zentel } & tablets 400 mg, № 1 & \multirow{2}{*}{$\begin{array}{l}\text { GlaxoSmithKline, } \\
\text { South Africa }\end{array}$} & 43,50 & 43,50 & 87,00 \\
\hline 9. & & $\begin{array}{c}\text { oral suspension (400 mg / } \\
10 \mathrm{ml} \text { ), vial } 10 \mathrm{ml} \text {, № } 1\end{array}$ & & 67,10 & 67,10 & 67,10 \\
\hline
\end{tabular}

In the second stage of the research, a pharmacoeconomic analysis of the dietary supplements use for the helminthiasis prevention was performed. The cheapest for the treatment course was «Phytoglycocide» in the form of capsules (126,83 UAH) and syrup
(275,88 UAH), and the most expensive - «Vormil Phyto» in the form of syrup (444,6 UAH) (Table 4). However, the use of dietary supplements is not in demand, which can be explained by the high price of these drugs for the treatment course.

The calculation of the costs for a course of treatment with herbal dietary supplements

\begin{tabular}{|c|c|c|c|c|c|c|c|}
\hline № & Drugs & $\begin{array}{l}\text { The form of } \\
\text { drug release }\end{array}$ & $\begin{array}{c}\text { Manufacturer, } \\
\text { country }\end{array}$ & Age & $\begin{array}{c}\text { The average } \\
\text { cost of } \\
\text { packaging, } \\
\text { UAH }\end{array}$ & $\begin{array}{l}\text { The cost of } \\
\text { the daily } \\
\text { dose, UAH }\end{array}$ & $\begin{array}{c}\text { The cost of } \\
\text { treatment } \\
\text { course, } \\
\text { UAH }\end{array}$ \\
\hline \multirow{5}{*}{1.} & \multirow{5}{*}{ Vormil Phyto } & \multirow{3}{*}{$\begin{array}{c}\text { syrup } 200 \mathrm{ml} \text {, } \\
\text { vial № } 1\end{array}$} & \multirow{5}{*}{$\begin{array}{c}\text { Mili Healthcare, } \\
\text { United } \\
\text { Kingdom }\end{array}$} & $3-6$ & \multirow{3}{*}{148,20} & 7,41 & 148,20 \\
\hline & & & & $6-12$ & & 14,80 & 296,40 \\
\hline & & & & $>12$ & & 22,20 & 444,60 \\
\hline & & \multirow{2}{*}{$\begin{array}{c}\text { capsules, } \\
\text { № } 60\end{array}$} & & $6-12$ & \multirow{2}{*}{156,70} & 5,22 & 104,40 \\
\hline & & & & $>12$ & & 7,83 & 156,60 \\
\hline \multirow{3}{*}{2.} & \multirow{3}{*}{ Vormitel } & \multirow{3}{*}{$\begin{array}{c}\text { syrup for oral } \\
\text { use } 100 \mathrm{ml} \text {, } \\
\text { vial № } 1\end{array}$} & \multirow{3}{*}{$\begin{array}{c}\text { Vorwärts } \\
\text { Pharma LLC, } \\
\text { Ukraine }\end{array}$} & $3-6$ & \multirow{3}{*}{157,95} & 15,80 & 221,20 \\
\hline & & & & $6-12$ & & 23,70 & 331,80 \\
\hline & & & & $>12$ & & 31,60 & 442,40 \\
\hline \multirow{3}{*}{3.} & \multirow{3}{*}{ Helmizin } & \multirow{3}{*}{$\begin{array}{c}\text { syrup } 100 \mathrm{ml} \text {, } \\
\text { vial № } 1\end{array}$} & \multirow{3}{*}{$\begin{array}{c}\text { EuBion } \\
\text { Corporation, } \\
\text { Poland }\end{array}$} & $3-6$ & \multirow{3}{*}{52,80} & 7,92 & 110,88 \\
\hline & & & & $6-12$ & & 10,56 & 147,84 \\
\hline & & & & $>12$ & & 21,12 & 295,68 \\
\hline
\end{tabular}


Continuation Table 4

\begin{tabular}{|c|c|c|c|c|c|c|c|}
\hline \multirow{3}{*}{4.} & \multirow{3}{*}{ Helmiplant } & \multirow{3}{*}{$\begin{array}{c}\text { syrup } 100 \text { ml, } \\
\quad \text { vial № } 1\end{array}$} & \multirow{3}{*}{$\begin{array}{c}\text { ICS } \\
\text { Eurofarmaco } \\
\text { SA, Moldova }\end{array}$} & $3-6$ & \multirow{3}{*}{289,00} & 28,90 & 202,30 \\
\hline & & & & $6-12$ & & 43,36 & 303,52 \\
\hline & & & & $>12$ & & 57,80 & 404,60 \\
\hline \multirow{3}{*}{5.} & \multirow{3}{*}{$\begin{array}{l}\text { Kuchikoo } \\
\text { from } \\
\text { helmints }\end{array}$} & \multirow{3}{*}{$\begin{array}{c}\text { syrup } 150 \mathrm{ml} \text {, } \\
\quad \text { vial № } 1\end{array}$} & \multirow{3}{*}{$\begin{array}{c}\text { Delta Medical } \\
\text { Promotions, } \\
\text { Switzerland }\end{array}$} & $3-6$ & \multirow{3}{*}{154,80} & 10,30 & 206,00 \\
\hline & & & & $6-12$ & & 15,45 & 309,00 \\
\hline & & & & $>12$ & & 20,60 & 412,00 \\
\hline \multirow{4}{*}{6.} & \multirow{4}{*}{$\begin{array}{l}\text { Phyto- } \\
\text { glistocide }\end{array}$} & capsules, 350 & \multirow{4}{*}{$\begin{array}{c}\text { PE Company } \\
\text { "Dana, Ya", } \\
\text { Ukraine }\end{array}$} & $6-12$ & \multirow{2}{*}{66,75} & 4,45 & 80,10 \\
\hline & & $\mathrm{mg}$, № 30 & & $>12$ & & 6,68 & 126,83 \\
\hline & & syrup $100 \mathrm{ml}$, & & $6-12$ & \multirow{2}{*}{96,80} & 9,68 & 174,24 \\
\hline & & vial № 1 & & $>12$ & & 14,52 & 275,88 \\
\hline
\end{tabular}

Therefore, according to the results of our analysis, the choice of drug depends on the age category, dosage form and manufacturer, considering that the price difference is not significant.

\section{Conclusions}

According to the results of the conducted researches it has been established that the most widespread in the territory of the region remains enterobiasis. Albendazole group agents in the form of tablets and suspensions are most commonly used for helminthiasis treatment. The drugs of choice are «Angelmex», «Vormil» and «Zentel», the choice of which depends on the age category.

\section{Prospects for the further researches}

It is promising to study the effectiveness of medicinal plants, phytodrugs and dietary supplements, both for the prevention and enhancement of treatment of parasitic

\section{Список літератури}

1. Гарник ТП. Лікарські рослини у комплексній, превентивній та відновно-реабілітаційній терапії хворих на гельмінтози (огляд літератури). Фітотерапія. Часопис. 2016;3;10-21.

2. Levecke B, Montresor A, Albonico M, Ame SM, Behnke JM, Bethony JM, et al. Assessment of anthelmintic efficacy of mebendazole in school children in six countries where soiltransmitted helminths are endemic. PLoS Negl Trop Dis [Internet]. 2014[cited 2020 Oct 15];8(10):e3204. Available from: https://www.ncbi.nlm.nih.gov/pmc/articles/PMC4191962/pdf/ pntd.0003204.pdf doi: 10.1371/journal.pntd.0003204

3. Vlaminck J, Cools P, Albonico M, Ame S, Ayana M, Cringoli $\mathrm{G}$, et al. Therapeutic efficacy of albendazole against soiltransmitted helminthiasis in children measured by five diagnostic methods. PLoS Negl Trop Dis [Internet]. 2019[cited 2020 Oct 15];13(8):e0007471. Available from: https://www.ncbi.nlm nih.gov/pmc/articles/PMC6675043/pdf/pntd.0007471.pdf doi: 10.1371/journal.pntd.0007471

4. Крамарьов СО. Сучасні підходи до лікування гельмінтозів. Современная педиатрия. 2016;5:25-9. doi: 10.15574/ SP.2016.77.25

5. Шульгай ОМ, Кабакова АБ, Мочульська ОМ, Шульгай АМА Застосування рослинних препаратів у лікуванні паразитозів у дітей з коморбідною патологією травної системи. Актуальні питання педіатрії, акушерства та гінекології. 2019;1:33-7. doi: https://doi.org/10.11603/24116-4944.2019.1.10178

6. Манжай ЮА, Вакал АП. Сучасний стан захворюваності на гельмінтози населення Сумської області. Природничі науки. 2019;16:75-8. doi: 10.5281/zenodo.3551644

7. Шадрин ОГ, Ковальчук АА, Герасимюк СИ, Туркин ЮВ, Кодруль ЮВ. Растительные средства в терапии гельминтозов у детей. Педиатрия. Восточная Европа. 2018;6(1):198-203.

8. Горленко ОМ, Поляк-Товт ВМ, Поляк МА. Гельмінтози: епідеміологія, клініка, діагностика та лікування. Проблеми клінічної педіатрії. 2013;2:10-4.

9. Єршова ІБ, Осичнюк ЛМ, Мочалова ГО. Гельмінтози у дітей. Перинатология и педиатрия. 2013;2:125-31.

\section{References}

1. Garnik T. Likars'ki roslyny u kompleksnii, preventyvnii ta vidnovno-reabilitatsiinii terapii khvorykh na hel'mintozy (ohliad literatury) [Medicinal plants in the complex, and preventive therapy for regeneration and rehabilitation for patients helminthiases (literary review)]. Fitoterapiia. Chasopys. 2016;3;10-21. (in Ukrainian)

2. Levecke B, Montresor A, Albonico M, Ame SM, Behnke JM, Bethony JM, et al. Assessment of anthelmintic efficacy of mebendazole in school children in six countries where soiltransmitted helminths are endemic. PLoS Negl Trop Dis [Internet]. 2014[cited 2020 Oct 15];8(10):e3204. Available from: https://www.ncbi.nlm.nih.gov/pmc/articles/PMC4191962/pdf/ pntd.0003204.pdf doi: 10.1371/journal.pntd.0003204

3. Vlaminck J, Cools P, Albonico M, Ame S, Ayana M, Cringoli $\mathrm{G}$, et al. Therapeutic efficacy of albendazole against soiltransmitted helminthiasis in children measured by five diagnostic methods. PLoS Negl Trop Dis [Internet]. 2019[cited 2020 Oct 15];13(8):e0007471. Available from: https://www.ncbi.nlm. nih.gov/pmc/articles/PMC6675043/pdf/pntd.0007471.pdf doi: 10.1371/journal.pntd.0007471

4. Kramarev SA. Suchasni pidkhody do likuvannia hel'mintoziv [Current approaches to the treatment of helminthiasis]. Sovremennaya pediatriya. 2016;5:25-9. doi: 10.15574/ SP.2016.77.25 (in Ukrainian)

5. Shul'hai OM, Kabakova AB, Mochul's'ka OM, Shul'hai AMA. Zastosuvannia roslynnykh preparativ u likuvanni parazytoziv $\mathrm{u}$ ditei z komorbidnoiu patolohiieiu travnoi systemy [Application of the herbal medication in treatment of parasitosis in children with comorbid pathology of the digestive system]. Aktual'ni pytannia pediatrii, akusherstva ta hinekolohii. 2019;1:33-7. doi: https://doi.org/10.11603/24116-4944.2019.1.10178 (in Ukrainian) 
6. Manzhaj YuA, Vakal AP. Suchasnyy̆ stan zakhvoriuvanosti na hel'mintozy naselennia Sums'koï oblasti [The current state of the incidence of helminthiases in the population of Sumy region]. Prirodničì nauki. 2019;16:75-8. doi: 10.5281/zenodo.3551644 (in Ukrainian)

7. Shadrin OG, Koval'chuk AA, Gerasimyuk SI, Turkin YuV, Kodrul' YuV. Rastitel'nye sredstva v terapii gel'mintozov u deteî [Herbal remedies in the treatment of helminthiasis in children]. Pediatriya. Vostochnaya Evropa. 2018;6(1):198-203. (in Russian)
8. Horlenko OM, Polyak-Toth VM, Polyak MA. Hel'mintozy: epidemiolohiia, klinika, diahnostyka ta likuvannia [Helminthiasis: epidemiology, clinical dates, diagnostics and treatment]. Problemy klinichnoi pediatrii. 2013;2:10-4. (in Ukrainian)

9. Yershova IB, Osychnyuk LM, Mochalova AA. Hel'mintozy u ditey̆ [Helminthiasis in children]. Perinatologiya i pediatriya. 2013;2:125-31. (in Ukrainian)

\section{Відомості про авторів}

Ежнед М.А. - асистент кафедри фармацевтичної ботаніки та фармакогнозії Вищого державного навчального закладу України «Буковинський державний медичний університет», м. Чернівці, Україна.

Захарчук О.І. - д.мед.н., професор, завідувач кафедри фармацевтичної ботаніки та фармакогнозії Вищого державного навчального закладу України «Буковинський державний медичний університет», м. Чернівці, Україна.

Горошко О.М. - к.фарм.н., доцент кафедри фармацевтичної ботаніки та фармакогнозії Вищого державного навчального закладу України «Буковинський державний медичний університет», м. Чернівці, Україна.

Матущак М.Р. - асистент кафедри фармацевтичної ботаніки та фармакогнозії Вищого державного навчального закладу України «Буковинський державний медичний університет», м. Чернівці, Україна.

Костишин Л.В. - асистент кафедри фармацевтичної ботаніки та фармакогнозії Вищого державного навчального закладу України «Буковинський державний медичний університет», м. Чернівці, Україна.

Сахацька I.M. - к.фарм.н, старший викладач кафедри фармацевтичної ботаніки та фармакогнозії Вищого державного навчального закладу України «Буковинський державний медичний університет», м. Чернівці, Україна.

Федюк Н.А. - лікар-інтерн Вищого державного навчального закладу України «Буковинський державний медичний університет», м. Чернівці, Україна.

Михайлюк Н.В. - викладач кафедри фармацевтичної ботаніки та фармакогнозії Вищого державного навчального закладу України «Буковинський державний медичний університет», м. Чернівці, Україна.

Волошин В.Л. - к.біол.н, асистент кафедри медичної біології та генетики Вищого державного навчального закладу України «Буковинський державний медичний університет», м. Чернівці, Україна.

\section{Сведения об авторах:}

Эжнед М.А. - ассистент кафедры фармацевтической ботаники та фармакогнозии Высшего государственного учебного заведения Украины «Буковинский государственный медицинский университет», г. Черновцы, Украина.

Захарчук А.И. - д.мед.н., профессор, заведующий кафедры фармацевтической ботаники та фармакогнозии Высшего государственного учебного заведения Украины «Буковинский государственный медицинский университет», г. Черновцы, Украина.

Горошко А.М. - к.фарм.Н., доцент кафедры фармацевтической ботаники та фармакогнозии Высшего государственного учебного заведения Украины «Буковинский государственный медицинский университет», г. Черновцы, Украина.

Матущак М.Р. - ассистент кафедры фармацевтической ботаники та фармакогнозии Высшего государственного учебного заведения Украины «Буковинский государственный медицинский университет», г. Черновцы, Украина.

Костишин Л.В. - ассистент кафедры фармацевтической ботаники та фармакогнозии Высшего государственного учебного заведения Украины «Буковинский государственный медицинский университет», г. Черновцы, Украина.

Сахацькая И.М. - к.фарм.н, старший преподаватель кафедры фармацевтической ботаники та фармакогнозии Высшего государственного учебного заведения Украины «Буковинский государственный медицинский университет», г. Черновцы, Украина.

Федюк Н.А. - врач-интерн Высшего государственного учебного заведения Украины «Буковинский государственный медицинский университет», г. Черновцы, Украина.

Михайлюк Н.В. - преподаватель кафедры фармацевтической ботаники и фармакогнозии Высшего государственного учебного заведения Украины «Буковинский государственный медицинский университет», г. Черновцы, Украина.

Волошин В.Л. - к.биол.н, ассистент кафедры медицинской биологии и генетики Высшего государственного учебного заведения Украины «Буковинский государственный медицинский университет», г. Черновцы, Украина. 
Information about authors:

Ezhned M.A. - Assistant Professor at the Department of pharmaceutical botany and pharmacognosy, Bukovinian State Medical University, Chernivtsi.

Zakharchuk O.I. - Doctor of Medical Sciences, Professor, Head of the Department of pharmaceutical botany and pharmacognosy, Bukovinian State Medical University, Chernivtsi.

Horoshko O.I. - Candidate of Pharmaceutical Sciences, Associate Professor at the Department of pharmaceutical botany and pharmacognosy, Bukovinian State Medical University, Chernivtsi.

Matushchak M.R. - Assistant Professor at the Department of pharmaceutical botany and pharmacognosy, Bukovinian State Medical University, Chernivtsi.

Kostyshyn L.V. - Assistant Professor at the Department of pharmaceutical botany and pharmacognosy, Bukovinian State Medical University, Chernivtsi.

Sakhatska I.M. - Candidate of Pharmaceutical Sciences, Senior Lecturer at the Department of pharmaceutical botany and pharmacognosy, Bukovinian State Medical University, Chernivtsi.

Fediuk N.A. - intern doctor, Bukovinian State Medical University, Chernivtsi.

Mykhailiuk N.V. - Teacher at the Department of pharmaceutical botany and pharmacognosy, Bukovinian State Medical University, Chernivtsi.

Voloshin V.L. - Candidate of Biologycal Sciences, Assistant Professor at the Department of Medical Biology and Genetics, Bukovinian State Medical University, Chernivtsi. 